Є.В. Крилов, В.К. Анікін

\title{
МЕТОДИ ТА ЗАСОБИ ПІДВИЩЕННЯ ЕФЕКТИВНОСТІ ФУНКЦІОНУВАННЯ ПРОГРАМНОГО ЗАБЕЗПЕЧЕННЯ СИСТЕМ РЕАЛЬНОГО ЧАСУ
}

\begin{abstract}
Вступ
Проблема забезпечення якості при створенні та впровадженні на промислових підприемствах систем автоматизованого управління та контролю особливу актуальність набула у зв'язку з тенденцією переносу акценту з кількісних показників на якісні. Життевий цикл розробки програмного забезпечення (ПЗ) систем реального часу (СРЧ) складається з наступних стадій: аналіз, проектування, комплексування та дослідна експлуатація.

Багатомірність якісних показників ПЗ СРЧ зумовлюеться тим, що на інтегрований рівень якості впливае багато різноманітних якісних характеристик. Так для програм управління і контролю важливими характеристиками є точність вхідних даних, діапазони зміни параметрів, час реакції, адаптивність до зовнішніх впливів, надійність функціонування, раціональне використання ресурсів ЕОМ, часові показники, мобільність та інші.
\end{abstract}

\section{Постановка задачі}

Замовник в технічному завданні визначає задані значення показників якості ПЗ СРЧ. 3 іншого боку, е створена для конкретної предметної області база рекомендацій, щодо поліпшення різних показників якості ПЗ СРЧ. Зрозуміло, що використання рекомендації впливае одразу на значення декількох показників якості. Цей вплив для одних показників може бути позитивним, а для інших від'емним. Тому задача вибору рекомендацій є оптимізаційна, та ії вирішення потребує наступних досліджень:

- розробити метод розрахунку показників якості фрагментів програм контролю та управління;

- розробити метод розрахунку коефіціентів структури для вузлів з циклічними процедурами;

- розробити спосіб добору рекомендацій щодо підвищення ефективності функціонування ПЗ СРЧ.

${ }^{0}$ (C) Є.В. Крилов, В.К. Анікін, 2007 


\section{Вирішення задачі}

Задача розрахунку заданих значень показників якості вирішуеться на стадії проектування.

Нехай вузол ПЗ складається з $k$ програмних компонент (ПК), які пов'язані структурною схемою $S$. Задані значення показників якості для вузла в цілому $-P_{3}^{y}$. Треба визначити набір векторів заданих значень показників якості для кожної ПК, що входить до складу вузла $\left(\left\{P_{3 j}\right\}, j=1, k\right)$. Ця задача має місце в зв'язку з тим, що ПК, які складають вузол, можуть бути неоднозначні з точки зору потреби забезпечення їх якості з наступних причин. По-перше, ПК вузла будуть мати в процесі експлуатації нерівні навантаження. Тому у формулі розрахунку показників якості ПК вузла повинен бути присутнім коефіціент структури $\left(K_{s}\right)$. По-друге, необхідно врахувати важливість забезпечення того чи іншого показника якості в тій чи інший ПК вузла. Покажемо необхідність введення коефіціента важливості $\left(K_{v}\right)$ на наступному прикладі. Будемо розглядати вузол, що складаеться з трьох ПК. Необхідно підтримувати заданий рівень показників якості “Стійкість”, “Ефективність часова”, “Зручність в експлуатації”. Та нехай кожна з ПК вузла володіє такими функціональними особливостями. Перша ПК виконуе важливі обчислення, друга виконуе складні та довгострокові обчислення і нарешті третя є унікальною (наприклад, в поданій ПК застосовуеться новий метод). Зрозуміло, що в такому вузлі доцільно особливу увагу приділити стійкості першої ПК, часовій ефективності другої та зручності в експлуатації третьої.

3 вище викладеного випливае, що задані значення показників якості ПК вузла можна визначити такою функціональною залежністю

$$
P_{3 i, j}=F\left(K_{s j}, P_{3 i}^{\beta}\right),
$$

де $j=1, k k$ - кількість ПК у вузлі;

$i=1, m m-$ кількість показників якості;

$P_{3 i, j}$ - задані значення $i$-го показника якості $j$-і ПК вузла;

$K_{s j}$ - коефріціент структури $j$-ї ПК вузла;

$K_{v i, j}$ - коефіцієнт важливості $i$-го показника якості $j$-ї ПК;

$P_{3 i}^{B}$ - задані значення $i$-го показника якості вузла.

\section{Вибір коефіціента важливості}

Коефіцієнт важливості визначається експертним шляхом. В результаті проведення експертизи ПК вузла отримуемо матрицю важливості розмірністю $m$ на $k$. Після нормування матриці $K_{v}^{\prime}$ одержуемо нормовану матрицю важливості $\left(K_{v}\right)$. Елементи матриць $K_{v}$ і $K_{v}^{\prime}$ пов'язані співвідношенням.

$$
K_{v i, j}=\frac{K_{v i, j}^{\prime} * k}{\sum_{p=1}^{k} K_{v i, p}^{\prime}} \quad \forall i=\overline{1, m},
$$

де $k$ - кількість ПК у вузлі. 


\section{Вибір коефіцієнтів структури}

Присутність блоків логічного переходу в структурі вузла надає його ПЗ властивість неоднорідності з точки зору завантаженості ПК вузла в процесі експлуатації ПЗ. Тому при розподілі значень заданих показників якості необхідно враховувати “місцеположення” ПК у структурній схемі вузла, яка визначає оцінку можливості виконання ПК $(W)$ при передачі керування вузловій ПК.

$$
P_{3 i, j}=l * W_{j} * P_{3 i}^{6} \forall i=\overline{1, m},
$$

де: $W_{j}$-оцінка можливості виконання $j$-ї ПК при передачі керування вузлу;

$l$ - коефіціент пропорційності;

$P_{3 i, j}$ - задане значення $i$-го показника $j$-ї ПК вузла;

$P_{3 i}^{b}$ - задане значення $i$-го показника якості вузла.

Коеріцієнт пропорційності $l$ визначаеться за формулою (4).

$$
l=\frac{k}{\sum_{t=1}^{k} W_{t}}
$$

Таким чином, коефіціент структури визначається за фрормулою (5)

$$
K_{s j}=\frac{k W_{j}}{\sum_{t=1}^{k} W_{t}},
$$

де $k$ - кількість ПК вузла;

$W_{j}$ - оцінка можливості виконання $j$-ї ПК при передачі керування вузлу;

$i$ - уявляе собою нормовану оцінку можливості виконання ПК при передачі керування вузлу.

Розглянемо вузол, на структуру якого накладені такі обмеження:

- у складі структурної схеми відсутні цикли;

- виконання ПК, які розташовані на різних гілках блока передачі керування (гілки “умова істина" i “умова хибна"), $е$ рівнозначними подіями.

Подамо структуру вузла $(S)$, елементи якої приймають бінарні значення (0 або 1) і визначаються з виразами (6), (7).

$$
S_{j, p}=1,
$$

якщо $j$-а ПК вузла належить $p$-й гілці структурної схеми вузла;

$$
S_{j, p}=0,
$$

в протилежному випадку,

де $j$ - номер ПК у вузлі ( $j=1, k ; k$ - кількість ПК у вузлі);

$p$ - номер гілки структурної схеми вузла $(p=1, l)$;

$l$ - кількість гілок структурної схеми вузла. 
Тоді оцінку можливості використання довільної ПК вузла можна визначити з виразу (8).

$$
W_{j}=\sum_{p=1}^{l} S_{j, p} * R_{p},
$$

де $R_{p}$ - оцінка можливості виконання $p$-ї гілки структурної схеми вузла.

Якщо урахувати, що оцінка можливості виконання $p$-ї гілки структурної схеми вузла дорівнюе

$$
R_{p}=\frac{}{12 * B_{p}}
$$

де $B_{p}$ - кількість умов, які належать $p$-й гілці структурної схеми вузла, то вираз (8) набуває вигляду

$$
W_{j}=\sum_{p=1}^{l} S_{j, p} * \frac{1}{2 * B_{p}}
$$

Покажемо послідовність визначення набору коефіцієнтів структури на прикладі вузла, структурна схема якого наведена на рис. 1.

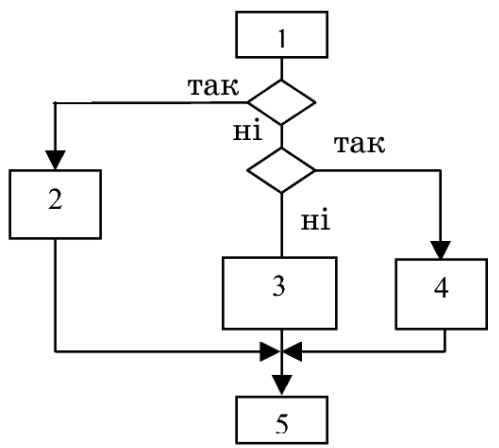

Рис. 1 - Структура вузла

3 рис. 1 видно, що вузол складається з п'яти ПК $(k=5)$. Структурна схема вузла має у своєму складі три гілки $(l=3): 1,2,5 ; 1,3,5 ; 1,4,5$. Матриця структури вузла $S$ має наступний вигляд:

\begin{tabular}{|l|l|l|l|l|l|}
\hline 1 & 2 & 3 & 4 & 5 & 6 \\
\hline 1 & 1 & 1 & 0 & 0 & 1 \\
\hline 2 & 1 & 0 & 1 & 0 & 1 \\
\hline 3 & 1 & 0 & 0 & 1 & 1 \\
\hline
\end{tabular}

Елементи вектора кількості умов $(B)$ набувають таких значень $B(1)=$ $1, B(2)=2, B(3)=2$. 
Визначимо вектор оцінок можливості використання ПК при передачі керування вузлу. Для цього скористаємося виразом (8)

$W_{1}=1, W_{2}=0.5, W_{3}=0.25, W_{4}=0.25, W_{5}=1$.

Визначимо значення коефіцієнтів структури ПК.

$K_{s 1}=\frac{5}{3} ; K_{s 2}=\frac{5}{6} ; K_{s 3}=\frac{5}{12} ; K_{s 4}=\frac{5}{12} ; K_{s 5}=\frac{5}{3}$.

Необхідно відзначити, що вище наведені формули дають точне рішення поставленої задачі лише в присутності вище вказаних обмежень. Якщо друге обмеження не виконується, але є можливість оцінити вірно сутність переходу по умовам “істинно" та "хибно", то залежність повинна бути скоректована з урахуванням ймовірностей переходів.

\section{Висновок}

Задачу оптимального добору заданих значень показників якості ПЗ можна подати у вигляді задачі математичного програмування. Лінійний характер цільової функції та обмежень дозволяе зробити висновок про можливість пристосування методів лінійного програмування.

Визначена формула розрахунку заданих значень показників якості ПЗ. Значення показників залежать від заданих значень показників якості вузла в цілому, структури ПЗ, важливості ПК, міри охоплення ПК циклічними процедурами. Структура ПЗ обліковуеться коефріцієнтом структури $\left(K_{s}\right)$, важливість ПК - коефіціентом важливості $\left(K_{v}\right)$, міра охоплення ПК циклічними процедурами - коефріцієнтом циклічності.

\section{Література}

1. Липаев В.В. Проектирование программного обеспечения. М.:Финансы и статистика.

2. Е.В. Бутаков. Методы создания качественного программного обеспечения. 